\title{
Carolingian Traditions and New Beginnings: The Coronation of Rudolph I of Upper Burgundy
}

\section{Andrea Hauff}

\section{(2) OpenEdition}

1 Journals

\section{Electronic version}

URL: https://journals.openedition.org/cem/14839

DOI: $10.4000 /$ cem.14839

ISSN: 1954-3093

\section{Publisher}

Centre d'études médiévales Saint-Germain d'Auxerre

\section{Electronic reference}

Andrea Hauff, "Carolingian Traditions and New Beginnings : The Coronation of Rudolph I of Upper Burgundy", Bulletin du centre d'études médiévales d'Auxerre | BUCEMA [Online], 22.1 | 2018, Online since 03 September 2018, connection on 22 September 2022. URL: http://journals.openedition.org/cem/ 14839 ; DOI: https://doi.org/10.4000/cem.14839

\section{This text was automatically generated on 22 September 2022}

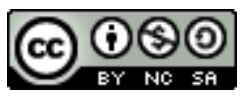

Creative Commons - Attribution-NonCommercial-ShareAlike 4.0 International - CC BY-NC-SA 4.0 https://creativecommons.org/licenses/by-nc-sa/4.0/ 
Carolingian Traditions and New Beginnings : The Coronation of Rudolph I of Upper Burgundy

Andrea Hauff

Introduction 
1 The Kingdom of Upper Burgundy, also called Transjurane Burgundy and once part of the Middle Kingdom, belongs to the first post-Carolingian kingdoms that came into existence at the end of the ninth century. In the year 888 , Charles the Fat (876-888), under whose reign all Carolingian territories had been reunited for the last time, died and Rudolph I (888-912), a member of the House of Welf and son of Conrad II the Younger (860/870), became king of Upper Burgundy. After the unification with the Kingdom of Lower Burgundy in the 940s, the realm became known as the Kingdom of Burgundy and remained as such until $1032^{1}$.

2 This article will investigate the beginnings of the Kingdom of Upper Burgundy and its ruling dynasty, the Rudolphians. For this

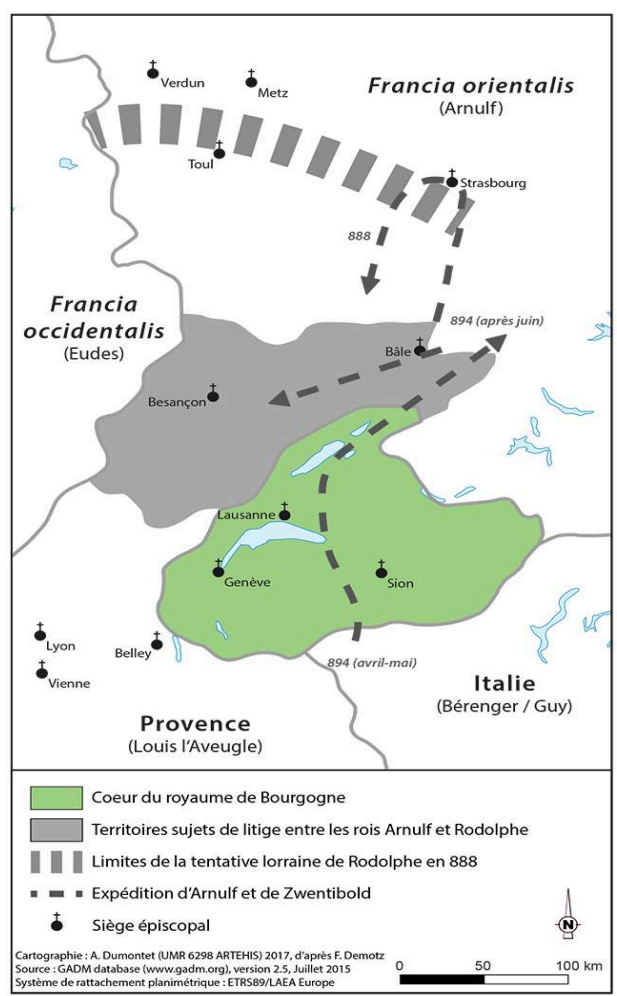
analysis, it seems worthwhile to consider the perspective of religion and to adopt Max Weber's approach of three types of legitimization of social authority ${ }^{2}$. Similar to other ruling dynasties in the Early Middle Ages, the reign of the Rudolphians was inseparably connected to the monasteries, the bishops and the clergy in Upper Burgundy ${ }^{3}$. A comprehensive analysis of this conjunction would be beyond the scope of this article, which mainly focuses on the rite of coronation of Rudolph I, who played a pivotal role as first Rudolphian king ${ }^{4}$. At the beginning, our study sheds some light on the ancestry of Rudolph I and his family. It will then focus on providing an analysis of the historiographical sources reporting on Rudolph's coronation, with particular emphasis on the chronicle of Regino of Prüm and the Annales Vedastini. Finally, by contrasting these sources, it will reassess the process of how Rudolph became king of Upper Burgundy.

\section{The initial phase of the Kingdom of Upper Burgundy}

3 As far as the beginnings of the Kingdom of Upper Burgundy are concerned, we should first take note of Rudolph's Welf ancestors ${ }^{5}$. Even if he himself was not directly coming from a Carolingian male-line, he had some family ties to the Carolingians : two sisters of his grandfather Conrad I the Elder ( $\dagger$ after 862), count of Auxerre, namely Judith ( $†$ 843), who was the second wife of Louis the Pious (814-840), and Hemma ( $†$ 876), who was the wife of Louis the German (843-876), were married to Carolingian kings ${ }^{6}$. Together with his brother Hugh the Abbot $(\dagger 886)^{7}$, Rudolph's father, Conrad II the Younger, changed sides from Eastern Frankish to Western Frankish and, thereupon, after the year 860 joined the Lotharingian party, thus supporting Lothar II (855-869), who had ceded the area of Transjurane Burgundy to his brother Louis II of Italy (840-875) in 859. Since Hucbert $(\dagger 864)$, a brother of Lothar's wife Teutberga 
(† after 869), had de facto control over Transjurane Burgundy as the lay-abbot of SaintMaurice d'Agaune, we may assume that Conrad was entrusted with the Transjurane area in order to remove Hucbert ${ }^{8}$. Conrad probably defeated him in 864 in a battle near Orbe $^{9}$ and became abbot of Saint-Maurice himself, which was a religious, geographical, and political centre of power in the Transjurane area at that time ${ }^{10}$. Thus, it is not surprising that Conrad's son Rudolph I issued his first surviving charter in 878 as humilis comes nec non et monasterii sancti Mauricii Agaunensis abba ${ }^{11}$. Additionally, Rudolph is referred to as marchio in the period before his coronation in $888^{12}$.

\section{The coronation of Rudolph I}

Due to the lack of a historiographical tradition of its own, the body of source material on the Kingdom of Upper Burgundy is unfortunately rather limited ${ }^{13}$, which is also the case with the coronation of Rudolph I. By contrast, the imperial coronation of Berengar I (888-924), for example, is reported in great detail by the Gesta Berengarii ${ }^{14}$. Thus, we can only presume that Rudolph's coronation took place after the death of Charles the Fat, on January 13th, 888 and before January 28th, $888^{15}$. Neither do we know exactly how Rudolph became king of Upper Burgundy, since the sources reporting on it are narrative, inconsistent, and, therefore, not very reliable. In addition, some of these historiographical sources, such as the Annales Lausannenses ${ }^{16}$ and the Annales Anglo-Saxonici ${ }^{17}$, do not offer much in the way of information, something not unusual for this kind of source material ${ }^{18}$. While the Annales Lausannenses were mainly written late in the High Middle Ages ${ }^{19}$, this is not the case with the Gesta Berengarii, which add in their glosses Hic [Rodulfus] noviter rex a Burgundionibus constitutus erat ${ }^{20}$, and the Annales Fuldenses, which note that Ruodulfus vero filius Chuonradi superiorem Burgundiam apud se statuit regaliter retenere ${ }^{21}$. Furthermore, it is important to note that neither the Gesta Berengarii, which, in fact, mention Upper Burgundy solely in this passage $^{22}$, nor the Annales Fuldenses, which, in addition to the events of the year 888, record also those of the year $894^{23}$, focus on the events in Upper Burgundy.

By contrast, the chronicle of Regino of Prüm provides unique details, although, similar to the Annales Fuldenses, it also reports on Upper Burgundy only in the context of interactions with the Eastern Frankish Kingdom ${ }^{24}$. It relates for the year 888 that Rudolph usurped the area of Upper Burgundy, assembled magnates and sacerdotes in Saint-Maurice d'Agaune, crowned himself and had himself called king ${ }^{25}$. It continues on reporting the conflict that took place between Rudolph and Arnulf of Carinthia ( $† 899)$, respectively his son Zwentibold $(\dagger 900)^{26}$. However, it is necessary to pose one central question in this context: how reliable is the chronicle of Regino in this affair? It is clear from the entirety of the report on the year 888 , which is about twice as long as the one given by the Annales Fuldenses, and, thus, provides additional information, that the author disapproves of the disintegration of the Carolingian realm and the emergence of non-Carolingian kingdoms as successors ${ }^{27}$. Besides, Rudolph, having Welf ancestors ${ }^{28}$ and being an opponent of Arnulf of Carinthia, is not presented in a favourable light throughout the whole chronicle, which is not unbiased towards Lotharingian affairs ${ }^{29}$. It should also be mentioned that, in contrast to the report given by the Annales Fuldenses, Regino, erroneously or not, states that Rudolph already withdrew in the Jura Mountains during the year $888^{30}$. In addition, it has been pointed out by Carlrichard Brühl that the chronicle is quite often inaccurate in describing coronations ${ }^{31}$. All in all, 
this presumable self-coronation of Rudolph in Saint-Maurice, where he was lay-abbot like his father before him $^{32}$ and where thus no other higher ranked ecclesiastical person had its $\operatorname{see}^{33}$, should be interpreted with caution, particularly because yet another detailed account of the coronation of Rudolph has survived ${ }^{34}$.

Reporting on the events of the year 888, the Annales Vedastini state that magnates from Upper Burgundy, having convened in Toul, requested the bishop of Toul, Arnald, to consecrate Rudolph, a task the bishop carried out ${ }^{35}$. The episcopal see of Toul, which belonged to the former Middle Kingdom ${ }^{36}$, must have been of geostrategic importance to Rudolph, who at that time probably sought to enlarge his territory, thereby competing with the King of East Francia $^{37}$ and possibly also with Guy of Spoleto $(\dagger 894)^{38}$. The question whether the bishop of Toul's $\mathrm{s}^{39}$ alleged partiality for Rudolph must be considered within the context of the confiscation of goods and the later recompense by Arnulf of Carinthia cannot be clearly traced ${ }^{40}$. Nonetheless, we may assume that Arnald strove to persevere against the influential neighbouring diocese of Metz, since Metz, similar to Compiègne, had already gained prominence as place for the coronation of the kings of West Francia, in contrast to Toul or even SaintMaurice d'Agaune ${ }^{41}$.

7 At first sight, one might interpret the report given by the Annales Vedastini as an ecclesiastical coronation or even as if Rudolph were anointed by Arnald of Toul, which seems to contradict the presumable self-coronation described by the chronicle of Regino. Yet, if we attempt to evaluate the degree of reliability of this report, we have to take into account that, first and foremost, the Annales Vedastini, written in the abbey of Saint Vaast, record Western Frankish affairs and, only marginally, address events in other regions like Italy or East Francia ${ }^{42}$. For instance, it is said that Charles the Fat was strangled, whereas the chronicle of Regino and the Annales Fuldenses note down a good death of the former emperor ${ }^{43}$. This also applies to Upper Burgundy, which is mentioned by the Annales Vedastini solely in this passage on the year 888 in the context of the coronation of Rudolph in Toul. This mention is embodied as a side note, after a remark on a new bishop in the diocese of Cambrai/Arras, in between the account of the coronation of Guy of Spoleto in Langres and that of his final return to Italy ${ }^{44}$. All in all, the report on the events after the death of Charles the Fat in the Annales Vedastini evidently focuses on the disputed succession in West Francia and should not be read as a reliable source for other parts of the disintegrated Carolingian Empire.

8 Moreover, analysing the two text passages on the coronation of Rudolph in the Annales Vedastini and in the chronicle of Regino more closely and comparing them with the aforementioned evidence reveals similarities when it comes to the terms and expressions used: in both texts, the rather unusual epithet nepos Hugonis abbatis is added to Rudolph's name. In addition to that, Regino uses the much more common term filius Cuonradi, a designation also used by the Annales Fuldenses, which do not title Rudolph as rex ${ }^{45}$. Besides, both texts avoid using the term «Burgundia » or "superior Burgundia » for Upper Burgundy, as do the Annales Fuldenses, but instead label it geographically by the terms "Iurus ", " Alpes », and "Alpes Penninae», which may be due to a Western Frankish tradition ${ }^{46}$. Although these textual parallels do not suffice as evidence, they might be seen as hints that Regino ${ }^{47}$ and the Annales Vedastini ${ }^{48}$ might have had a common source they used for writing about the coronation of Rudolph. In support of this argument, the two sources should be examined as a whole and 
compared in detail. Such a detailed comparative examination, however, cannot be accomplished within the scope of this article.

Next, it is necessary to examine what benedici in regem facere/petere means in the Annales Vedastini. All in all, it is used in four text passages reporting on royal coronations :

1. Louis III and his brother Carlomann II are crowned kings of Western Francia in $879^{49}$.

2. Odo is crowned king of Western Francia in $888^{50}$.

3. Rudolph I is crowned king of Upper Burgundy in $888^{51}$.

4. Zwentibold is crowned king of Lotharingia in $895^{52}$.

Since the ecclesiastical ritual of coronation existed in the Western Frankish Kingdom as a continuous tradition ever since the anointing of Charles the Bald in $848^{53}$ and is documented by ordines, there is no doubt that the phrase benedici in regem facere could mean that Louis, Carlomann and Odo were consecrated kings ${ }^{54}$. However, Martin Lintzel and Walter Mohr have already suggested that the Annales Vedastini were influenced by this Western Frankish tradition and use the phrase for designating every rite of coronation, whether ecclesiastical or not ${ }^{55}$. As a direct parallel to the report on the coronation of Rudolph, neither the chronicle of Regino ${ }^{56}$ nor the Annales Fuldenses ${ }^{57}$ mention that Zwentibold was consecrated or anointed ${ }^{58}$. Furthermore, it would have been the only anointing of an Eastern Frankish king in the ninth century. Franz-Reiner Erkens attempts to explain this purported exception by asserting the existence of a Lotharingian tradition that was based on the consecration of Charles the Bald in Metz in 869 and found its continuation in the anointing of Rudolph in Toul in $888^{59}$. As there is no other evidence than the Annales Vedastini, this does not seem convincing to me ${ }^{60}$. Thus, I claim that the phrase benedici in regem facere in the context of the coronations of Zwentibold and Rudolph does not inevitably imply that an anointing took place, but must be understood as a phrase designating a ritual of enthronement instead.

\section{Conclusion}

11 In the light of all these arguments, neither an anointing nor a self-coronation of Rudolph can be proven beyond doubt. Previous studies have often simply combined the two main sources. Instead, the differences in the accounts of the coronation of Rudolph between the chronicle of Regino, where Rudolph, son of Conrad and nephew of Hugh the Abbot, is said to have usurped Upper Burgundy, called together magnates and bishops - not mentioned by name - in Saint-Maurice d'Agaune and then crowned himself ${ }^{61}$, and the Annales Vedastini, where magnates of Upper Burgundy - not mentioned by name either - are said to have assembled in Toul and requested Rudolph, nephew of Hugh the Abbot, to be crowned by the bishop of Toul ${ }^{62}$, should be interpreted as being mainly caused by the divergent intentions and traditions on which these historiographical sources are based ${ }^{63}$. Therefore, I suggest that the coronation and presumable anointing of Rudolph have to be seen as one inseparable rite of enthronement, which might have consisted of secular and possibly also ecclesiastical elements ${ }^{64}$. As shown above, the lack of evidence does not allow us to draw any conclusions regarding the precise nature of the coronation of Rudolph. Nevertheless, it seems to me that, if there had been an ecclesiastical ritual of consecration and anointing following the Western Frankish tradition, some evidence of it should have survived. 
12 Neither can the place of the coronation of Rudolph be determined with ultimate certainty due to the diverging accounts presented by the sources, whereas the coronations of Conrad the Peaceful (937-993) and his son Rudolph III (993-1032) are documented to have taken place in Lausanne ${ }^{65}$. However, Saint-Maurice d'Agaune, situated at the very heart of the Rudolphians' central territories and, what is perhaps even more important, the location at which Rudolph II (911/912-937), who succeeded his father Rudolph as king of Upper Burgundy, was probably crowned and buried, seems to be the most reasonable place for the coronation of the first Rudolphian king ${ }^{6}$. In addition, Rudolph is also likely to have been present in Toul at the beginning of the year 888 ; the conclusion that some sort of coronation may have taken place during that time thus cannot be entirely dismissed.

13 To conclude, a lot of research has been devoted to support the thesis stating that these new kings - who, like Rudolph, came into power during the gradual disintegration of the Carolingian realm - were in urgent need of ecclesiastical legitimization, which they attempted to gain from an anointing ${ }^{67}$. In contrast to this thesis, recent scholarship argues that rulers' transitions depended, above all, on the respective current power structure, and that legitimization was often only constructed afterwards by the implementation of ecclesiastical rituals or reports of a tendentious historiography ${ }^{68}$. As Janet Nelson argues, it is furthermore essential to realize that inauguration rituals and anointings are to be understood as interdependent processes between kings and magnates, who were represented by the anointer as an ecclesiastical person ${ }^{69}$. In the case of the Kingdom of Upper Burgundy, I thus challenge the thesis that Rudolph needed ecclesiastical legitimization in the form of anointing because, as lay-abbot of Saint-Maurice d'Agaune, which was to become the royal monastery of the Kingdom of Upper Burgundy, Rudolph did have a strong religious centre of his very own at his disposal, while simultaneously holding political power as well, as François Demotz has shown $^{70}$. In the case of Odo, the first non-Carolingian king of West Francia, Bernd Schneidmüller judges the power structure in a similar way ${ }^{71}$. As far as all the other late and post-Carolingian kingdoms are concerned, I am not in a position to assess whether anointing as a Carolingian tradition of coronation was a suitable or even necessary instrument for establishing and stabilizing the rule of a non-Carolingian king, but I strongly plead for the question to be re-examined in a broader context.

Reçu : 27 juillet 2017 - Accepté : 13 avril 2018

\section{NOTES}

1. For a detailed account of the historical development of the Kingdom of Upper Burgundy, cf. R. POUPARDIN, Le royaume de Bourgogne (888-1038). Étude sur les origines du royaume d'Arles, Paris, 1907 ; F. DEMOTZ, La Bourgogne, dernier des royaumes carolingiens (855-1056). Roi, pouvoirs et élites autour du Léman, Lausanne, 2008, and further articles such as, for example, L. RIPART, « Le royaume de Bourgogne de 888 au début du XII siècle ", in G. BÜHRER-THIERRY and T. DESWARTE (ed.), Pouvoirs, Église et société dans les royaumes de France, de Bourgogne et de Germanie. De 888 aux premières années $d u$ XII siècle, Paris, 2008, p. 72-98; ID., "Le royaume rodolphien de Bourgogne (fin IX ${ }^{\mathrm{e}}$-début 
$\mathrm{XI}^{\mathrm{e}}$ siècle) ", in M. GAILLARD et al. (ed.), De la mer du Nord à la Méditerranée. Francia Media, une région au cœur de l'Europe (c. 840-c. 1050), Luxemburg, 2011, p. 429-452.

2. M. WEBER, Wirtschaft und Gesellschaft. Grundriß der verstehenden Soziologie, 5th ed., Tübingen, 1980, p. 122-148.

3. Cf. J.L. NELSON, "Tenth-Century Kingship Comparatively", in D. ROLLASON, C. LEYSER and H. Williams (ed.), England and the Continent in the Tenth Century. Studies in Honour of Wilhelm Levison (1876-1947), Turnhout, 2010, p. 293-308, here p. 295-297.

4. See F. DEMOTZ, La Bourgogne..., op. cit., p. 101-139.

5. For the following, cf. B. SCHNEIDMÜLLER, Die Welfen. Herrschaft und Erinnerung (819-1252), Stuttgart, 2000, p. 63-72 ; F. DEMOTZ, L'an 888, le royaume de Bourgogne. Une puissance européenne au bord du Léman, Lausanne, 2012, p. 13-21 ; ID., La Bourgogne..., ibid., p. 87-91 ; L. RIPART, « Le royaume... ", op. cit., p. 436 sq.; R. PARISOT, Le royaume de Lorraine sous les Carolingiens, 843-923, Paris, 1898, p. 133-135, 261-263, 352 and 487 sq.

6. P. E. SCHRAMM, «Wahl, Krönung und Staatssymbolik in den Burgundischen Königreichen (von 879 bzw. 888 an). Mit Ausblicken auf die Zeit der Vereinigung mit Deutschland (von 1033 bis zum späten Mittelalter)», in ID., Kaiser, Könige und Päpste. Gesammelte Aufsätze zur Geschichte des Mittelalters, t. 2 : Vom Tode Karls des Großen [814] bis zum Anfang des 10. Jahrhunderts, Stuttgart, 1968, p. 249-286, here p. 273 ; G.SERGI, "Genesi di un regno effimero. La Borgogna di Rodolfo I ", Bollettino storico-bibliografico subalpino, 87 (1989), p.5-44, here p. 19-22; G. CASTELNUovo, «La Burgondie carolingienne et rodolphienne. Prémices et développement d'un royaume», in P. PARAVY (ed.), Des Burgondes au royaume de Bourgogne ( $V^{e}-X^{e}$ siècle). Espace politique et civilisation, Grenoble, 2002, p. 183-210, here p. 191 sq.

7. K. VON KALCKSTEIN, « Abt Hugo aus dem Hause der Welfen Markgraf von Neustrien », Forschungen zur deutschen Geschichte, 14 (1874), p. 38-128.

8. Die Regesten des Regnum Italiae und der burgundischen Regna, t.3/1 (Die Karolinger im Regnum Italiae 840-887/888), ed. H. ZIELINSKI, in J. F. BÖHMER, Regesta Imperii. Die Regesten des Kaiserreichs unter den Karolingern, 751-918 [926], Cologne/Vienna, 1991, $\mathrm{n}^{\circ}$ 179. For Hucbert as lay-abbot, cf. L. RIPART, "Les temps séculiers (IX ${ }^{\mathrm{e}}-\mathrm{X}^{\mathrm{e}}$ siècles)", in B. ANDENMATTEN and L. RIPART (ed.), L'abbaye de SaintMaurice d'Agaune, 515-2015, t. 1 (Histoire et archéologie), Gollion, 2015, p. 135-149, here p. 139-141; S. MACLEAN, Kingship and Politics in the Late Ninth Century. Charles the Fat and the End of the Carolingian Empire, Cambridge, 2003, p. 72 sq.

9. Regesta Imperii, I..., 3/1, op. cit., $\mathrm{n}^{\circ} 228$.

10. M. ZUFFEREY, Die Abtei Saint-Maurice d'Agaune im Hochmittelalter (830-1258), Göttingen, 1988, p. 52-62 ; L. RIPART, «Les temps séculiers... », op. cit., p. 141 ; ID., "Saint Maurice et la tradition régalienne bourguignonne (443-1032) », in P. PARAVY (ed.), Des Burgondes..., op. cit., p. 211-239, here p. 220-225.

11. Die Urkunden der burgundischen Rudolfinger, ed. T. SCHIEFFER, MGH DD Burg., Munich, 1977, $\mathrm{n}^{\circ} 1$, p. 92 sq.

12. Die Urkunden..., ibid., $\mathrm{n}^{\circ} 2$, p. 95 : Rodulfus comes nec non etiam inclitus marchius. Diplomata Karoli III, ed. P. KEHR, MGH DD Karl, Berlin, 1937, n 112, p. 179 : Ruodulfi fidelis et dilecti marchionis nostri. Cf. S. MACLEAN, Kingship and Politics..., op. cit., p.67-69 ; F. DEMOTZ, La Bourgogne..., op. cit., p. 67 ; for the general use of dux, marchio, and comes, cf. H.-W. GOETZ, «Dux» und "Ducatus». Begriffs- und verfassungsgeschichtliche Untersuchungen zur Entstehung des sogenannten "jüngeren » Stammesherzogtum an der Wende vom neunten zum zehnten Jahrhundert, Bochum, 1977, p. 73-87.

13. J.-Y. MARIOTTE, "Le Royaume de Bourgogne et les souverains allemands du haut Moyen Âge (888-1032) ", Mémoires de la Société pour l'histoire du droit et des institutions des anciens pays bourguignons, comtois et romands, 23 (1962), p. 163-183, here p. 163 ; H. E. MAYER, « Die Alpen und das Königreich Burgund », in Die Alpen in der europäischen Geschichte des Mittelalters. Reichenau-Vorträge 
1961-1962, Konstanz/Stuttgart, 1965, p. 57-76, here p. 61 sq. ; L. RIPART, «Le royaume... », op. cit., p. 431 sq. ; R. POUPARDIN, Le royaume de Bourgogne..., op. cit., p. 12 ; B. SCHNEIDMÜLLER, Die Welfen..., op. cit., p. 76-78 ; A. HAUFF, «The Kingdom of Upper Burgundy and the East Frankish Kingdom at the beginning of the 10th century ", History Compass, 15 (2017), p. 1-12, here p. 2 sq.

14. Gesta Berengarii, ed. P. WINTERFELD, MGH Poetae, t. 4/1, Berlin, 1899, IV, v. 83-200, p. 397-401. For an analysis, cf. F. BOUGARD, «Le couronnement impérial de Bérenger $\mathrm{I}^{\text {er }}$ (915) d'après les Gesta Berengarii imperatoris ", in M. COUMERT et al. (ed.), Rerum gestarum scriptor. Histoire et historiographie au Moyen Âge. Mélanges Michel Sot, Paris, 2012, p. 329-343.

15. R. POUPARDIN, Le royaume de Bourgogne..., op. cit., p. 10 sq.; L. DUPRAZ, "L'avènement de Rodolphe I et la naissance du royaume de Bourgogne transjurane (6 janvier 888) ", Schweizerische Zeitschrift für Geschichte, 13 (1963), p. 177-195 ; L. RIPART, « Le royaume... », op. cit., p. 437.

16. Annales Lausannenses, ed. G. WAITZ, MGH Scriptores (in folio), t. 24, Hanover, 1879, a. 888, p. 780 : Ruodulfus rex fuit ordinatus anno Domini 888.

17. Annales Anglo-Saxonici, ed. R. PAULI, MGH Scriptores (in folio), t. 13, Hanover, 1881, a. 887, p. 107 : Et Rodulfus medium accepit regnum. Cf. J. L. NELSON, "Alfred's Carolingian Contemporaries ", in T. REUTER (ed.), Alfred the Great. Papers from the Eleventh-Centenary Conferences, Aldershot/Hants, 2003, p. 293-310, here p. 301.

18. Cf. J. L. NELSON, «Inauguration Rituals ", in EAD., Politics and Ritual in Early Medieval Europe, London, 1986, p. 283-307, here p. 284-289.

19. C. SANTSCHI, Les évêques de Lausanne et leurs historiens des origines au XVIII siècle. Érudition et société, Lausanne, 1975, p. 61-77 ; F. DEMOTZ, La Bourgogne..., op. cit., p. 80.

20. Gesta Berengarii..., op. cit., I, v. 88, p. 362.

21. Annales Fuldenses cont. Ratisb., ed. F. KURZE, MGH SS rer. Germ., 7, Hanover, 1891, a. 888, p. 116. For a contextualization and interpretation of the whole report on 888, cf. most recently S. GROTH, In regnum successit. "Karolinger » und «Ottonen » oder das «Ostfränkische Reich » ?, Frankfurt am Main, 2017, p. 277 sq. and 340-342.

22. Cf. A. EBENBAUER, Carmen historicum. Untersuchungen zur historischen Dichtung im karolingischen Europa, Vienna, 1978, p. 175. For the origin and sources of the glosses in the Gesta Berengarii, cf. F. DUPLESSIS, «Les sources des gloses des Gesta Berengarii et la culture du poète anonyme ", Aevum, 89 (2015), p. 205-263.

23. Annales Fuldenses cont. Ratisb..., op. cit., a. 894, p. 124 sq.

24. Chronicon Reginonis, ed. F. KURZE, MGH SS rer. Germ., 50, Hanover, 1890, a. 894, p. 142.

25. Chronicon Reginonis..., ibid., a. 888, p. 130 : Per idem tempus Ruodolfus filius Cuonradi, nepos Hugonis abbatis, de quo supra meminimus, provintiam inter Iurum et Alpes Penninas occupat et apud sanctum Mauritium adscitis secum quibusdam primoribus et nonnullis sacerdotibus coronam sibi imposuit regemque se appellari iussit.

26. Chronicon Reginonis..., ibid., a. 888, p. 130 : Post haec mittit legatos per universum regnum Lotharii et suasionibus pollicationibusque episcoporum ac nobilium virorum mentes in sui favorem demulcet. Quod cum nunciatum esset Arnulfo, ilico cum exercitu super eum irruit ; ille per artissima itinera fuga dilapsus in tutissimis rupium locis salutis presidium quaesivit [...].

27. For the causa scribendi of the chronicle, cf. S. AIRLIE, " "Sad stories of the death of kings". Narrative Patterns and Structures of Authority in Regino of Prüm's Chronicle », in E. M. TYLER and R. BALZARETTI (ed.), Narrative and History in the Early Medieval West, Turnhout, 2006, p. 105-131; S. MACLEAN, «Insinuation, Censorship and the Struggle for Late Carolingian Lotharingia in Regino of Prüm's Chronicle », English Historical Review, 124 (2009), p. 1-28 ; L. BOHNENKAMP, « Regino von Prüm und die religiöse Bedeutung der Geschichtsschreibung im Frühmittelalter », Concilium medii aevi, 14 (2011), p. 289-317 ; J.-L. KUPPER, « La part de l'empereur Lothaire $\mathrm{I}^{\mathrm{er}}$. Aspects politiques, institutionnels et religieux (843-1056)», in M.GAILLARD et al. (ed.), De la mer du Nord..., op. cit., p. 11-39, here p. 17. Cf. also J. L. NELSON, « Alfred's Carolingian... », op. cit., p. 301 sq. 
28. See above.

29. Cf. K. F. WERNER, « Les Robertiens », in M. PARISSE and X. BARRAL ALTET (ed.), Le roi de France et son royaume autour de l'an Mil, Paris, 1992, p. 15-26, here p. 16 sq. ; s. AIRLIE, « Unreal Kingdom. Francia Media under the Shadow of Lothar II ", in M. GAILLARD et al. (ed.), De la mer du Nord..., op. cit., p. 339-356, here p. 355 sq.

30. See above.

31. C. BRÜHL, "Fränkischer Krönungsbrauch und das Problem der "Festkrönungen" ", Historische Zeitschrift, 194 (1962), p. 265-326, here p. 277 and 301.

32. See above.

33. For the bishops in the Kingdom of Upper Burgundy, cf. F. DEMOTZ, La Bourgogne..., op. cit., p. 121-127. Cf. also ibid., p. 80.

34. Cf. B. SCHNEIDMÜLleR, Die Welfen..., op. cit., p. 78 ; A. HOFMEISTER, Deutschland und Burgund im früheren Mittelalter. Eine Studie über die Entstehung des Arelatischen Reiches und seine politische Bedeutung, Darmstadt, 1963, p. 36.

35. Annales Vedastini, ed. B. VON SIMSON, MGH SS rer. Germ., 12, Hanover/Leipzig, 1909, a. 888, p. 64 sq. : At hi qui ultra Iurum atque circa Alpes consistunt, Tullo adunati Hrodulfum nepotem Hugonis abbatis per episcopum dictae civitatis benedici in regem petierunt; qui et ita egit.

36. For the geo-strategic position of Toul, cf. I. WERNET and D. WERNET, Toul. Die Geschichte einer französischen Lagerfestung, Aachen, 2009, p. 6 sq.; H. BÜTTNER, «Die politische Erschließung der westlichen Vogesen im Früh- und Hochmittelalter », Zeitschrift für die Geschichte des Oberrheins, 50 (1937), p. 365-404, here p.365-369; ID., «Toul im Vogesenraum während des Früh- und Hochmittelalters ", in P. WENTZCKE (ed.), Schicksalswege am Oberrhein. Beiträge zur Kultur- und Geistesgeschichte, zur Wirtschafts- und Staatenkunde, Heidelberg, 1952, p. 112-128, here p. 119 sq. ; T. BAUER, Lotharingien als historischer Raum. Raumbildung und Raumbewußtsein im Mittelalter, Cologne/Weimar/Vienna, 1997, p. 265 ; F. DEMOTZ, La Bourgogne..., op. cit., p. 86 sq.

37. Cf. Chronicon Reginonis..., op. cit., a. 888, p. 130 ; Annales Fuldenses cont. Ratisb..., op. cit., a. 888, p. 116. For the conflict between Rudolph and Arnulf of Carinthia, cf., for example, H. BÜTTNER, Geschichte des Elsaß, t. 1 : Politische Geschichte des Landes von der Landnahme bis zum Tode Ottos III., Berlin, 1939, p. 161-166; w. MOHR, «Die Rolle Lothringens im zerfallenden Karolingerreich », Revue belge de philologie et d'histoire, 47 (1969), p. 361-398, here p. 373-379; J. SCHNEIDER, Auf der Suche nach dem verlorenen Reich. Lotharingien im 9. und 10. Jahrhundert, Cologne/Weimar/Vienna, 2010, p. 102 sq.

38. Die Regesten des Regnum Italiae und der burgundischen Regna, t. 3/2 (Das Regnum Italiae in der Zeit der Thronkämpfe und Reichsteilungen 888 [850]-926), ed. H. ZIELINSKI, in J. F. BÖHMER, Regesta Imperii. Die Regesten des Kaiserreichs unter den Karolingern 751-918 [926/962], Cologne/Weimar/Vienna, 1998, $\mathrm{n}^{\circ} 863 \mathrm{sq}$. For the purported ambitions of Guy, cf. esp. R. HIESTAND, Byzanz und das Regnum Italicum im 10. Jahrhundert, Zurich, 1964, p. 48-50; P. DELOGU, « Vescovi, conti e sovrani nella crisi del Regno Italico (Ricerche sull'aristocrazia carolingia in Italia, III) », Annali della Scuola Speciale per Archivisti, 8 (1968), p. 3-72, here p. 35-37.

39. For the person of Arnald, cf. Gesta episcoporum Tullensium, ed. G. WAITZ, MGH Scriptores (in folio), t. 8, Hanover, 1848, p. 638. Cf. L. DUCHESNE, Fastes épiscopaux de l'ancienne Gaule, t. $3:$ Les provinces du nord et de l'est, Paris, 1915, p. 66 ; R. РARIsOT, Le royaume..., op. cit., p. 130, 396, 421, 428, 472 sq., 496 and 507 ; в. MORRET, Stand und Herkunft der Bischöfe von Metz, Toul und Verdun im Mittelalter, Düsseldorf, 1911, p. 58; M. GAILLARD, «Frothaire, évêque de Toul», in M. PARISSE (ed.), La correspondance d'un évêque carolingien. Frothaire de Toul (ca. 813-847) avec les lettres de Theuthilde, abbesse de Remiremont, Paris, 1998, p. 11-26, here p.13; G. BÖNNEN, Die Bischofsstadt Toul und ihr Umland während des hohen und späten Mittelalters, Treves, 1995, p. 33.

40. Diplomata Arnolfi, ed. P. KEHR, MGH DD Arn, Berlin, 1940, n 112, p. 165. Cf. w. MOHR, «Imperium Lothariensium ", Jahrbuch für westdeutsche Landesgeschichte, 13 (1987), p. 1-42, here p. 34 sq. 
opposing R. POUPARDIN, Le royaume de Bourgogne..., op. cit., p. 15 ; R. PARISOT, Le royaume..., ibid., p. 491, 504 and 708; E. HLAWITSCHKA, Lotharingien und das Reich an der Schwelle der deutschen Geschichte, Stuttgart, 1968, p. 80 sq.; F. DEMOTZ, La Bourgogne..., op. cit., p. 85 and 118 ; cf. also E. MARTIN, Histoire des diocèses de Toul, de Nancy \& de Saint-Dié, t. 1, Nancy, 1900, p. 126 sq.

41. For a comparison between these places, cf. M.ZUFFEREY, Die Abtei Saint-Maurice..., op.cit., p. 61 sq. ; cf. also F. DEMOTZ, La Bourgogne..., ibid., p. 85 sq. A short overview of the coronation places of the Western Frankish kings offers M. BUR, «Reims, ville des sacres », in Le sacre des rois, Paris, 1985, p. 39-48.

42. Cf. S. KASCHKE, "Nachtrag", in R.RAU(ed.), Quellen zur karolingischen Reichsgeschichte, t. 2 : Jahrbücher von St.Bertin, Jahrbücher von St.Vaast, Xantener Jahrbücher, Darmstadt, 2002, p. 401-412, here p. 407-409; ID., «Annales Vedastini », in G. DUNPHY (ed.), Encyclopedia of the Medieval Chronicle, Leiden/Boston, 2010, p.94; R. POUPARDIN, Le royaume de Provence sous les Carolingiens (855-933 ?), Paris, 1901, p. 150.

43. Annales Vedastini..., op. cit., a. 887, p. 64 : Karolus vero post amissum imperium fertur a suis strangulatus. Cf. Chronicon Reginonis..., op. cit., a. 888, p. 128 sq.; Annales Fuldenses cont. Ratisb..., op.cit., a.887, p.116. Cf. also S. MACLEAN, Kingship and Politics..., op.cit., p.194. For a further inaccuracy in the report of the Annales Vedastini on the year 888, cf. E. HLAWITSCHKA, " Kaiser Wido und das Westfrankenreich ", in G. ALTHOFF et al. (ed.), Person und Gemeinschaft im Mittelalter. Karl Schmid zum fünfundsechzigsten Geburtstag, Sigmaringen, 1988, p. 187-198, here p. 192.

44. Annales Vedastini..., ibid., a. 888, p. 64 sq. : Pauci vero ex Burgundia Widonem Lingonis civitate per Geilonem eiusdem civitatis episcopum regem sibi creaverunt. [...] Wido vero rex factus, audiens Odonem in Francia creatum regem, cum his qui se sequi deliberaverant rediit Italiam. For Guy of Spoleto, see above. 45. Cf. S. GROTH, In regnum successit..., op. cit., p. 396.

46. For the supposed different traditions of naming Upper Burgundy, cf. R. POUPARDIN, Le royaume de Provence..., op. cit., Paris, 1901, p. 285-290 ; ID., Le royaume de Bourgogne..., op. cit., p. 182-184; B. BLIGNY, «Le royaume de Bourgogne", in w. BRAUNFELS (ed.), Karl der Grosse. Persönlichkeit und Geschichte. Lebenswerk und Nachleben, Düsseldorf, 1965, p. 247-268, here p. 261 and 266 ; K. H. FLATT, «Zum Begriff Burgund », Jahrbuch des Oberaargaus, 49 (2006), p. 63-72, here p. 64.

47. For the sources used by Regino, cf. K. F. WERNER, «Zur Arbeitsweise des Regino von Prüm », Die Welt als Geschichte, 19 (1959), p. 96-116 ; A. BRACKMANN, « Die politische Bedeutung der MauritiusVerehrung im frühen Mittelalter ", Sitzungsberichte der Preußischen Akademie der Wissenschaften, Philosophisch-Historische Klasse, 30 (1937), p. 279-305, here p. 283 sq. ; s. KASCHKE, "Nachtrag », in R. RAU (ed.), Quellen zur karolingischen Reichsgeschichte, t. 3 : Jahrbücher von Fulda, Reginos Chronik, Notkers Taten Karls, Darmstadt, 2002, p. 449-461, here p. 454 sq.; S. MACLEAN, History and Politics in Late Carolingian and Ottonian Europe. The Chronicle of Regino of Prüm and Adalbert of Magdeburg, Manchester/New York, 2009, p. 18-52.

48. For the sources of the Annales Vedastini, cf. T. MOMMSEN, « Zu den Annales Vedastini », Neues Archiv der Gesellschaft für ältere deutsche Geschichtskunde, 16 (1891), p. 430 sq. ; S. KASCHKE, « Annales Vedastini... ", op. cit.

49. Annales Vedastini..., op.cit., a.879, p. 45 : Hugo vero Hludowicum et Karlomannum per manus Ansegisi archiepiscopi benedici fecit in reges. Cf. J. VERDIER, « Les rois Louis III et Carloman, leur sacre à Ferrières, septembre 879 ", Bulletin de la Société d'émulation de l'arrondissement de Montargis, 46 (1979), p. 39-42 ; J. L. NELSON, Hincmar of Reims on King-Making. The Evidence of the Annals of St. Bertin, 861-882, Aldershot/Brookfield, 1999, p. 16-32, here p. 20 sq.; W. FAŁKOWSKI, « La monarchie en crise permanente. Les Carolingiens après la mort de Charles Le Chauve », in W. FAŁKOWSKI and Y. SASSIER, Le monde carolingien. Bilan, perspectives, champs de recherches, Turnhout, 2009, p. 333-355, here p. 344-348 ; C. BRÜHL, «Fränkischer Krönungsbrauch...», op.cit., p. 325 ; S. GROTH, In regnum successit..., op. cit., p. 328-333. 
50. Annales Vedastini..., ibid., a. 888, p. 64 : Convenerunt itaque qui Odonem advocarunt Compendio palatio atque cum consensu eorum qui sibi consentiebant per manus Waltheri archiepiscopi benedici sibi in regnum fecerunt. Cf. o. GUILLoT, "Les étapes de l'accession d'Eudes au pouvoir royal », in Media in Francia. Recueil de mélanges offert à Karl Ferdinand Werner à l'occasion de son $65^{\circ}$ anniversaire par ses amis et collègues français, Maulévrier, 1989, p. 199-223 ; B. SCHNEIDMÜLLER, Karolingische Tradition und frühes französisches Königtum. Untersuchungen zur Herrschaftslegitimation der westfränkischfranzösischen Monarchie im 10. Jahrhundert, Wiesbaden, 1979, p. 105-121; C. BRÜHL, «Fränkischer Krönungsbrauch... », ibid., p. 325.

51. See above.

52. Annales Vedastini..., op. cit., a. 895, p. 75 : filiumque suum rex Arnulfus in praesentia Odoni regis nomine Zuendebolchum benedici in regem fecit eique concessit regnum quondam Hlotharii. Cf. R. PARISOT, Le royaume..., op. cit., p. 516 ; J. SCHNEIDER, Auf der Suche..., op. cit., p. 118 ; C. BRÜHL, « Fränkischer Krönungsbrauch... ", op. cit., p. 326.

53. Die Regesten des Westfrankenreichs und Aquitaniens, t. 2/1 (Die Regesten Karls des Kahlen 840 [823]-877), ed. I. FEES, in J. F. BÖHMER, Regesta Imperii. Die Regesten des Kaiserreichs unter den Karolingern 751-918 [987], Vienna/Weimar/Cologne, 2007, nº 599.

54. P. E. SCHRAMM, «Die Krönung bei den Westfranken und Angelsachsen von 878 bis um 1000 ", Zeitschrift der Savigny-Stiftung für Rechtsgeschichte, Kan. Abt., 54 (1934), p. 117-242, here p. 119-149; R.-H. BAUTIER, «Sacres et couronnements sous les Carolingiens et les premiers Capétiens. Recherches sur la genèse du sacre royal français ", in ID. (ed.), Recherches sur l'histoire de la France médiévale. Des Mérovingiens aux premiers Capétiens, Aldershot/Brookfield, 1991, p. 7-56 ; A. DIERKENS, «Krönung, Salbung und Königsherrschaft im karolingischen Staat und in den auf ihn folgenden Staaten ", in M. KRAMP (ed.), Krönungen. Könige in Aachen, Geschichte und Mythos, t. 1, Mayence, 2000, p. 131-139, here p. 135-137 ; F.-R. ERKENS, Herrschersakralität im Mittelalter. Von den Anfängen bis zum Investiturstreit, Stuttgart, 2006, p. 117-122.

55. M. LINTZEL, Heinrich I. und die fränkische Königssalbung, Berlin, 1955, p. 29 ; w. MOHR, "Arnulfs lothringische Politik auf den Wormser Reichstagen der Jahre 894 und 895 », Archivum Latinitatis Medii Aevi, 26 (1956), p. 167-176, here p. 172-174. Cf. also C. ERDMANN, « Der ungesalbte König », Deutsches Archiv, 2 (1938), p. 311-340, here p. 320.

56. Chronicon Reginonis..., op.cit., a. 895, p.143: Post haec Arnulfus Wormatiam venit ibique optimatibus ex omnibus regnis suae ditioni subditis sibi occurrentibus conventum publicum celebravit; in quo conventu omnibus assentientibus atque collaudantibus Zuendibolch filium regno Lotharii prefecit.

57. Annales Fuldenses cont. Ratisb..., op. cit., a. 895, p. 126 : Zwentibaldus ergo filius regis infulam regni a patre suscipiens in Burgundia et omni Hlotharico regno receptis eiusdem regni primoribus rex creatus est. 58. Cf. T. BAUER, « Zwentibold (870-900), König von Lotharingien. Ein merk-würdiger Heiliger », in F. IRSIGLER and G. MINN (ed.), Porträt einer europäischen Kernregion. Der Rhein-Maas-Raum in historischen Lebensbildern, Treves, 2005, p. 16-38, here p. 21.

59. F.-R. ERKENS, Herrschersakralität..., op. cit., p.121 sq.; cf. C. BRÜHL, «Fränkischer Krönungsbrauch... », op. cit., p. 296-298; F. DEMOTZ, La Bourgogne..., op.cit., p. 84-86. For the coronation of Charles the Bald in Metz, cf. w. SCHLESINGER, « Zur Erhebung Karls des Kahlen zum König von Lothringen 869 in Metz », in E. HLAWITSCHKA (ed.), Königswahl und Thronfolge in fränkischkarolingischer Zeit, Darmstadt, 1975, p. 287-324.

60. Cf. J. SCHNEIDER, Auf der Suche..., op. cit., p. 118.

61. See above.

62. See above.

63. Cf., for example, R. POUPARDIN, Le royaume de Provence..., op. cit., p. 149 sq. ; W. MOHR, « Imperium Lothariensium... », op. cit., p. 34-37 ; F. DEMOTZ, La Bourgogne..., op. cit., p. 80-86.

64. For the difficulties in interpreting rites of enthronement, cf. J.L. NELSON, "The Lord's Anointed and the People's Choice. Carolingian Royal Ritual», in D. CANNADINE and S. PRICE (ed.), 
Rituals of Royalty. Power and Ceremonial in Traditional Societies, Cambridge/New York/Melbourne, 1987, p. 137-180 ; C. BRÜHL, «Fränkischer Krönungsbrauch... », op. cit., p. 294 ; R. SCHIEFFER, « Die Ausbreitung der Königssalbung im hochmittelalterlichen Europa», in M. BECHER (ed.), Die Mittelalterliche Thronfolge im europäischen Vergleich, Ostfildern, 2017, p.43-80, here p. 43 sq.; S. PATZOLD, « Wie bereitet man sich auf einen Thronwechsel vor ? Überlegungen zu einem wenig beachteten Text des 11. Jahrhunderts », in ibid., p. 127-162, here p. 130-136.

65. Die Urkunden der burgundischen Rudolfinger..., op. cit., $\mathrm{n}^{\circ}$ 102, p. 258-260. Cf. R. POUPARDIN, Le royaume de Bourgogne..., op. cit., p. 66 and 113.

66. Cf. A. BRACKMANN, "Politische Bedeutung... », op. cit., p. 283 sq. ; M. ZUfFEREY, Die Abtei SaintMaurice..., op. cit., p. 61 sq. ; L. RIPART, « Les temps séculiers... », op. cit., p. 142-145.

67. Cf., for example, M. LINTZEL, Heinrich I..., op. cit., p. 27-31; G. EITEN, Das Unterkönigtum im Reiche der Merovinger und Karolinger, Heidelberg, 1907, p. 191 ; R. POUPARDIN, Le royaume de Bourgogne..., op. cit., p. 14 ; G. SERGI, « Genesi di un regno effimero... », op. cit., p. 30 sq. ; L. BOEHM, « Rechtsformen und Rechtstitel der burgundischen Königserhebungen im 9. Jahrhundert. Zur Krise der karolingischen Dynastie ", in E. HLAwiTsCHKA (ed.), Königswahl und Thronfolge..., op. cit., p. 325-398 ; F.-R. ERKENS, Herrschersakralität..., op. cit., p. 121 sq.; F. DEMOTZ, L'an 888..., op. cit., p. 23 sq.; R. SCHIEFFER, « Die Ausbreitung der Königssalbung... », op. cit., p. 46-51.

68. A broad overview of case studies of different regions and times offers M. BECHER (ed.), Die Mittelalterliche Thronfolge..., op. cit. Cf. also L. KÖRNTGEN, «Möglichkeiten und Grenzen religiöser Herrschaftslegitimation. Zu den Dynastiewechseln 751 und 918/919 », in W. POHL and V. WIESER (ed.), Der frühmittelalterliche Staat - europäische Perspektiven, Vienna, 2009, p. 369-389; S. GROTH, In regnum successit..., op. cit., p. 108-111.

69. J. L. NELSON, «Inauguration Rituals... », op. cit., p. 294 sq. ; cf. also M. A. CONN, « Rites of KingMaking in Tenth-Century England», in M. Gosman, A. VANDERJAGT and J. VEenstra (ed.), The Propagation of Power in the Medieval West, Groningen, 1997, p. 111-127, here p. 123-125.

70. F. DEMOTZ, «Saint Maurice et les rois de Bourgogne du lien identitaire à la sainteté symbolique ", in N. BROCARD, F. VANNOTTI and A. WAGNER (ed.), Autour de saint Maurice, Saint-Maurice, 2012, p. 147-160 ; ID., La Bourgogne..., op. cit., p. 83 sq. ; cf. also G. COUTAZ, "L'Abbaye de SaintMaurice d'Agaune autour de l'an Mil», Vallesia, 52 (1997), p. 3-12, here p. 7 ; for earlier times B. H. ROSENWEIN, «One Site, many Meanings. Saint-Maurice d'Agaune as a Place of Power in the Early Middle Ages », in M. DE JONG, F. THEUWS and C. VAN RHJJ (ed.), Topographies of Power in the Early Middle Ages, Leiden et al., 2001, p. 271-290. For other ways Rudolph used to increase his legitimacy, cf. J. NOWAK, "The Burgundian "visage". Seals between Tradition and Innovation ", Bucema, 21/2 (2017), p. 1-18, here p. 2 sq., online [https://journals.openedition.org/cem/14861].

71. B. SCHNEIDMÜLLER, Karolingische Tradition..., op. cit., p. 106 sq.

\section{ABSTRACTS}

Cet article vise à éclairer les débuts du royaume de Bourgogne qui naît en 888 aux bords du lac Léman et à mieux comprendre l'essor de la dynastie régnante. L'attention se focalise d'abord sur les origines de Rodolphe I $^{\text {er }}$ et de sa famille, avant de porter un regard sur les sources narratives témoignant du couronnement de Rodolphe $\mathrm{I}^{\mathrm{er}}$ en 888 , en particulier, la chronique de Réginon de 
Prüm et les Annales Vedastini. Enfin, à la lumière de ces sources, l'article vise à réévaluer la question de l'accession de Rodolphe à la couronne de la Bourgogne transjurane.

INDEX

Mots-clés: couronnement, intronisation, onction, légitimation, Rodolphe Ier

Keywords: coronation, enthronement, anointing, legitimization, Rudolph I

\section{AUTHOR}

ANDREA HAUFF

Regesta Imperii, université de Gießen 